\title{
Kralj mučenik in sproščena opatinja: dva netipična svetnika iz istega družinskega gnezda
}

Alenka Divjak

Center biotehnike in turizma Grm Novo mesto, ul. Slavka Gruma 66, 8000 Novo mesto https://orcid.org/0000-0002-6531-6714

alenka.divjak@arnes.si

\begin{abstract}
Članek primerja dva svetnika, člana kraljevske družine v anglosaškem kraljestvu Northumbriji, brata in sestro, sv. Oswalda, kralja mučenca, in sv. Aebbe, opatinjo. Članek razpravlja tudi o začetnih zadržkih Cerkve v Northumbriji glede vzpostavitue kulta sv. Oswalda (634-642), za kar si je prizadevala Oswaldova družina ob podpori prebivalstva. Vnasprotju z Oswaldom, ki je bil kljub globoki vernosti izrazito vpet vposvetno življenje, je bila njegova (pol)sestra Aebbe (ok. 615-683) dejavna kot opatinja in ustanoviteljica samostanske skupnosti v Coldinghamu (današnja južna Škotska). Zavzemanje za Oswaldov kult se je začelo že v prvih letih po njegovi smrti, medtem ko se je Aebbin kult začel wveljavljati šele v dvanajstem stoletju, toda drugače kot sv. Oswald Aebbe ni nikoli dosegla mednarodne prepoznavnosti, useeno pa je bila zelo cenjena krajevna svetnica zaradi ozdravitvenih čudežev.
\end{abstract}

Ključne besede: cerkvena zgodovina / krščanstvo / 7. stoletje / Northumbrija / redovništvo / svetniki / sv. Oswald iz Northumbrije / sv. Aebbe iz Coldinghama

\section{Sv. Oswald iz Northumbrije - težavni začetki in trajni uspeh}

Pokristjanjevanje Anglosasov, prednikov današnjih Angležev, je brez dvoma osrednji dogodek v zgodovini Anglije. Krščanstvo je prineslo med Anglosase vrsto pomembnih gospodarskih, pravnih in kulturnih inovacij (Turner in Fowler 249-263) in jih trajno povezalo z antično-krščansko civilizacijo, zlasti z Rimom kot duhovnim središčem krščanske civilizacije na evropskem Zahodu (Pengelley 67-68). Uspešno pokristjanjenje anglosaške Anglije v sedmem stoletju je v pomembni meri zasluga kraljevskih družin, ki so tedaj vladale različnim anglosaškim kraljestvom, in sicer Northumbriji, Merciji, Vzhodni Angliji, Kentu, Essexu, Sussexu in Wessexu. Vladarji anglosaških kraljestev so si s svojim sodelovanjem s Cerkvijo in papeštvom povečali ugled in utrdili prevlado (Swanton 9-11), 
Cerkev pa je v zahvalo za podporo mnoge člane kraljevskih družin razglasila za svetnike.

Cerkev na splošno ni imela težav z vzpostavljanjem kulta svetnic, ki so izvirale iz anglosaških kraljevskih rodbin. Mnoge med njimi so bile vdove, ločenke, neporočene hčere in druge sorodnice, ki so se odrekle posvetnemu življenju in se odločile za redovništvo, s čimer so zadostile cerkveni zahtevi po odpovedi posvetnemu življenju kot nujnemu pogoju za sanktifikacijo. Svetost njihovih moških sorodnikov pa je predstavljala za Cerkev trši oreh. Če se je kateri med njimi umaknil v samostan ali postal puščavnik, je vsaj v teoriji ustrezal tipu Antona Puščavnika in Martina iz Toursa, ki sta bila znana asketa in sta se prav tako umaknila iz posvetnega življenja. Njuni življenji sta služili kot model za mnoga druga življenja svetnikov, vitae, mož in žena, ki sicer niso umrli mučeniške smrti, ker so že živeli v dobi po letu 313, ko je bilo preganjanje kristjanov dejansko ustavljeno, krščanska vera pa vedno vplivnejša, so se pa popolnoma predali religioznemu življenju. Ker so živeli asketsko in odmaknjeno, so veljali za duhovne junake.

Tudi med anglosaškimi vladarji in moškimi člani kraljevskih družin so se našli taki, ki so se odločili za meništvo, toda svetniki so - presenetljivo in v nasprotju $s$ hagiografsko teorijo - postali le redki med njimi. Duhovščina je bila namreč v praksi zadržana do tovrstnih abdikacij, ker je razumela pomen močnih vladarjev za razvoj in obrambo dežele (Stancliffe 157-158). Toda še bolj je bila Cerkev zadržana do ideje, da bi razglašala za svetnike vladarje, ki so padli v boju proti poganom. Podoba vladarja mučenca svetnika, ki doseže svetništvo na bojnem polju, pa čeprav v boju proti nevernikom, je za Cerkev brez dvoma predstavljala zadrego in neprijetno novost. Ti vladarji so bili v trenutku smrti kljub svojim krščanskim vrlinam še vedno laiki in pripadniki posvetnega sveta in jim svetništvo po tedanjih merilih Cerkve preprosto ni pripadalo.

Cerkveni pomisleki glede kraljev mučencev so prišli do izraza zlasti v začetni fazi vzpostavljanja kulta sv. Oswalda iz Northumbrije, najbolj znanega anglosaškega svetnika doma in v tujini. Noben drug anglosaški svetnik ni dosegel podobne ali enake prepoznavnosti niti na Otoku niti na Kontinentu in prav tako ni kult nobenega med njimi doživel toliko preobrazb $\mathrm{v}$ teku časa in pokazal toliko trdoživosti in vsebinske prožnosti. Toda sam proces sanktifikacije sv. Oswalda ni potekal gladko in ravno v Northumbriji je prišlo do prelomne inovacije na področju kulta svetnikov, ki pa je ni sprožila Cerkev, temveč Oswaldova družina, potomci kralja Ide iz Bernicije (447-559), tj. Idingi, ki so vzpostavili kult sv. Oswalda (634-642), kralja mučenca, 
ki je padel $v$ boju proti poganom, in to $-\mathrm{v}$ začetni fazi - mimo Cerkve in ob podpori prebivalstva.

Najobsežnejši in najstarejši zapis o sv. Oswaldu se nahaja v Cerkveni zgodovini ljudstva Anglov (Historia Ecclesiastica Gentis Anglorum; okrajšano HE) ki jo je v prvi tretjini osmega stoletja napisal Beda Venerabilis (Častitljivi) (673-735), menih in učenjak iz samostana Jarrow v Northumbriji. Podatki o Oswaldu so zbrani zlasti v tretji knjigi, zapis o razširitvi njegovega kulta na Irsko in Frizijo ob koncu sedmega stoletja pa se nahaja še $v$ četrti knjigi (HE 4.14) in vsi ti podatki, povezani med sabo v smiselno celoto, podajajo naslednjo sliko. Oswald, sin umorjenega northumbrijskega kralja Æthelfritha z materjo Acho in sorojenci okoli 616 odide v izgnanstvo na sever Britanije, v gelsko kraljestvo Dalriado, ki je obsegalo del današnje zahodne Škotske in severne Irske, kjer se s svojo družino pokristjani, nauči irsko in se duhovno poveže z irskimi menihi na otoku Ioni, duhovnem središču irskega krščanstva na Otoku. V domovino se vrne po smrti materinega brata Edwina, leta 633, ki se je v času svoje vladavine leta 627 pokristjanil skupaj $\mathrm{z}$ družino, dvorom in prebivalstvom, toda po njegovi smrti $\mathrm{v}$ bitki proti združeni koaliciji poganskih Mercijcev in krščanskih Britancev (Valižanov) je kraljestvo zapadlo $\mathrm{v}$ poganstvo. Leto dni pozneje je Oswaldu v znani bitki pri Heavenfieldu uspelo premagati valižanskega vladarja Cadwallo, ki je leto dni prej v zavezništvu z mercijskim kraljem Pendo povzročil Edwinov poraz. Oswald vzpostavi svojo oblast in, kar je še pomembnejše, v deželo pokliče irske menih z otoka Ione, ki jim podari otoček Lindisfarne $\mathrm{v}$ bližini Bamburgha, svoje prestolnice, kjer irski menihi postavijo znani samostan in vzpostavijo sedež škofije za celotno kraljestvo. Oswald ponovno pokristjani deželo in učinkovito vlada, dokler ne pade v bitki pri Maserfeldu leta 642 proti mercijskemu kralju Pendi, star 38 let.

Oswalda je nasledil mlajši brat Oswy (642-670), ki se je po Oswaldovi smrti znašel v občutnih težavah, vendar je bil kos položaju in je uspešno obvladal vse svoje notranje in zunanje sovražnike. Leto dni po bitki pri Maserfeldu je Oswyju uspelo najti bratovo glavo in roke, ki jih je kralj Penda po bitki nataknil na kole. Glavo je preselil v Lindisfarne, roke pa v kraljevsko rezidenco v Bamburghu, kjer so zgradili cerkev sv. Petra in vanjo namestili dragocene relikvije. Oswaldovo truplo je bilo kasneje, v sedemdesetih ali osemdesetih letih sedmega stoletja, pokopano v samostanu Bardney Minster v Lindesyju v Merciji na pobudo kraljice Osthryth, Oswyjeve hčere (Bintley 171-181).

Oswy je pri vzpostavitvi kulta oral ledino in postavljal na glavo ustaljene hagiografske predstave. Poraz v bitki je tradicionalno veljal za 
sramoto, razen tega je bil Oswald obglavljen, njegovo truplo pa razsekano na kose, kar je bila v anglosaški dobi usoda usmrčenih kriminalcev. Za nameček, kriminalci niso bili pokopani na cerkvenih pokopališčih, tako da je tudi po smrti med njimi in običajnimi smrtniki vladala občutna fizična in duhovna razdalja. Vseeno je Oswyju uspel veliki met. Kljub Oswaldovemu porazu in poniževalnemu ravnanju z njegovimi posmrtnimi ostanki, ki so si ga privoščili zmagoviti Mercijci, mu je uspelo bratov poraz spremeniti v bleščečo moralno zmago, brata pa iz poraženca v kralja mučenca, ki je padel v borbi proti poganom (Dyson 42-43), kar je bila inovativna in drzna propagandna poteza. Prvič se je namreč zgodilo, da je bil vladarjev poraz po zaslugi energičnega in sposobnega sorodstva spremenjen v veličastno duhovno zmago (glej Damon), ki je premaganemu vladarju prinesla status svetnika, njegovi družini pa ugled brez primere. Tudi običajni ljudje so ne samo sprejeli Oswaldov kult za svojega, ampak so dejavno pripomogli $\mathrm{k}$ njegovemu razvoju $\mathrm{z}$ obiskovanjem in čaščenjem krajev, ki so bili povezani z njim. Zdravilne moči so pripisovali zlasti dvema krajema, povezanima z Oswaldom, Heavenfieldu, kjer je vladar dosegel sijajno zmago na začetku svoje vladavine, in Maserfeldu, kjer je zgubil življenje (Runstedler 13-15).

Toda Cerkev je bila zadržana (Thacker 98-99), ker jo je skrbelo, da bi se z razglasitvijo Oswalda za svetnika obnovile predkrščanske predstave o božanski naravi vladarjev, ki so v poganski dobi veljali za potomce Wodena in drugih germanskih bogov (Moisl 215). Z uveljavitvijo čaščenja kraljev svetnikov bi si utegnile kraljevske družine namreč povrniti svojo božansko-polbožansko naravo, ki so jo izgubile s pokristjanjenjem. Cerkev je vzpodbujala miselnost, da so vladarji Kristusovi predstavniki na Zemlji, nikakor pa ni hotela priznati svetniškega položaja vladarju, bojevniku, ki je bil do zadnjega trenutka vpet $\mathrm{v}$ posvetno življenje in je padel v bitki, pa čeprav proti poganom.

Istočasno so Cerkev v Northumbriji vznemirjali studenci in vodni izviri, ki so imeli pomembno vlogo v poganskem svetu (Cubitt 57, 61), kar je prišlo do izraza tudi v Oswaldovem primeru. Prav tako je Cerkev skrbelo dejstvo, da je bil Oswaldov kult poseben v tem smislu, da njegovi telesni ostanki niso bili pokopani na enem samem mestu, temveč so različni deli njegovega telesa počivali v različnih samostanih (Rollason 81). Tovrstni način pokopa je vzbujal nelagodje $\mathrm{v}$ srednjeveški Angliji, kjer so številni samostani gradili svojo prepoznavnost kot varuhi domnevno celovitih in nerazpadlih teles svetnikov. Anglosasi so glede pokopa umrlih spoštovali rimsko pravo, ki je poudarjalo in varovalo telesno integriteto umrlih, kar je bilo v skladu z vrednotami evropskega Zahoda (Rollason 80). 
Skrb pa je vzbujala tudi odsekana Oswaldova glava. Glave odsekanih sovražnikov so bile namreč fetiš $\mathrm{v}$ germanski in keltski mitologiji (MacKenzie 144-147). To pojasnjuje, zakaj so menihi v Lindisfarnu Oswaldovo glavo sprejeli, jo spoštljivo pokopali, niso pa je bili pripravljeni častiti kot relikvijo in tudi niso bili pripravljeni vzpodbujati kulta obglavljenega vladarja. Še bolj jih je verjetno zmotilo, da jim je Oswy izročil samo glavo, ne pa tudi rok, ki jih je dal pokopati v Bamburghu, dinastičnem središču Idingov (MacKenzie 154), s čimer je nedvomno ohranjal spomin na Oswaldovo bojevniško naravo.

Cerkev je začela mehčati svoje stališče šele v sedemdesetih letih sedmega stoletja, ko je bil ustanovljen samostan v Hexamu leta 674, v bližini Heavenfielda, in tedaj je kult začel dobivati bolj cerkvene poteze. Poudarek je bil zlasti na čaščenju križa, ki ga je Oswald postavil pred svojo zmagovito bitko s Cadwallo, in na čudežih, ki imajo izrazito meniški značaj, saj se dogajajo v samostanskem okolju med menihi in ne med navadnimi ljudmi tako kot v Maserfeldu. Če je Oswy brata bolj povezoval s Maserfeldom, krajem njegovega poraza in mučeništva, je bila Cerkev bolj naklonjena Heavenfieldu, prizorišču Oswaldove zmage, ki je imelo bistveno manj spornih poganskih potez (MacKenzie 178-179).

Toda do resnične sprave med vladarsko in cerkveno strujo je prišlo šele v začetku osmega stoletja, ko so se končali spori med kraljevsko rodbino in tamkajšnjim najvišjim cerkvenim predstavnikom sv. Wilfridom, ki se je zapletel v spore z Oswyjevim sinom in naslednikom Ecgfrithom (670-685), Ecgfrithovo drugo ženo Eormenburg in Ecgfrithovo sestro Osthryth. Ta sprava je ugodno vplivala na razvoj in razširjenost kulta sv. Oswalda ne samo v Northumbriji, ampak po celotnem Otoku, in ker so se Anglosasi ravno tedaj dejavno vključili v misijonarske dejavnosti na Kontinentu, ki jih je vzpodbuja družina frankovskih Karolingov, je Oswald že tedaj dosegel mednarodno prepoznavnost v samostanskih okoljih tedanje zahodne Evrope.

\section{Historia ecclesiastica}

Beda je bil tako kot njegovi nadrejeni prvotno zadržan do ideje o Oswaldu kot svetniku mučencu, ki pade na bojnem polju. Ne omenja ga v zgodnji verziji svoje Martirologije, v svoji Chronica Maiora pa pripiše glavne zasluge za začetek krččanstva v Northumbriji kralju Edwinu in škofu Pavlinu, ki je vodil pokristjanjevanje $\mathrm{v}$ Edwinovem času (Thacker 112-113). Beda je pripisal Oswaldu pomembno vlogo 
šele v svoji Cerkveni zgodovini, ki je veličasten opis vzpona krščanstva v Angliji in kjer so predstavljeni vzorni vladarji, najvišji duhovniki in zgledne opatinje, ki so bili vsi skupaj pionirji pri pokristjanjevanju Anglije. Ko je Beda premagal začetne zadržke do Oswalda kot svetnika mučenca, je predstavil v svoji Cerkveni zgodovini njegovo idealizirano podobo. To je očitno v mnogih segmentih, kjer kljub Bedovemu trudu prihajajo na dan stvarna dejstva, ki prikazujejo Oswalda v vlogi vladarja, ki je vladal v turbulentni dobi, v kateri je potekal neusmiljeni boj za preživetje. Prav tako je jasno, da Beda odobrava vojaške in vladarske sposobnosti posvetnih vladarjev, od katerih pričakuje, da bodo svojo vernost izživeli v posvetnem življenju. Do vladarjev v najboljših letih in pri največji moči, ki so se umaknili v samostane, je imel učeni menih zadržke (Foot 25-51; Higham, "The Shaved « 11-12). Beda je bil kljub svoji zavezanosti samostanskemu življenju državotvoren (Burch 145), kar je med drugim potrdil s posvetitvijo svoje Cerkvene zgodovine kralju Ceolwulfu, ki je prišel na oblast leta 729 po izumrtju Oswyjeve linije.

\section{Vladar in pokristjanjevalec}

V Cerkveni zgodovini Oswalda odlikujejo pobožnost, ponižnost, radodarnost do revežev, vzdrževanje reda, uveljavljanje prava, razširjanje krščanstva in prijateljski odnosi s Cerkvijo. Beda zlasti hvali Oswaldovo vnemo pri razširjanju krščanstva. Ker Aidan, irski menih z Ione, ki je postal prvi škof v Lindisfarnu, tedaj še ni znal angleško, ga je Oswald spremljal po deželi in prevajal njegove pridige.

Cerkvena zgodovina tudi ohrani nepozaben prizor, ki slavi Oswaldovo darežljivost. Aidan in Oswald sedita skupaj za mizo za veliko noč, ko Oswald izve, da pred palačo čaka množica siromakov. Oswald jim da odnesti veliko srebrno posodo, polno hrane, in naroči, naj jo zdrobijo na drobne kose in drobce razdelijo kot miloščino. Navdušeni Aidan se je dotaknil Oswaldove desne roke in izjavil, da naj ta roka nikoli ne strohni. Na tej točki je mogoče potegniti vzporednico med Oswaldom, ki da zdrobiti srebrno posodo in njene fragmente razdeliti med množico, in sv. Martinom, ki prereže svoj vojaški plašč in ga deli z beračem (Mertens 10, 36-37), kar je verjetno eden najbolj ikoničnih prizorov vseh časov v zahodnoevropski hagiografiji.

Aidan je spremenil Oswaldovo roko v simbol darežljivosti in miroljubnosti, zapisi o Oswaldu, ki so nastali med Britanci (Valižani) in Irci v sedmem, osmem in devetem stoletju pa nas opozorijo še na drugi, namreč posvetni, vojaški in folklorni vidik Oswaldovih rok. Tako 
valižanska Historia Brittonum iz začetka devetega stoletja omenja njegovo zmago nad Cadwallo, omeni tudi njegov poraz pri Maserfeldu, razen tega pa mu nadene vzdevek Belo/Bleščeče rezilo, ki simbolizira božanskost njegovega meča in s tem lastnikovo božansko moč, kar pomeni, da je bil Oswald junak keltskega folklornega izročila (Ziegler, "Through" \$18). Različni irski anali pa še bolj očitno poudarjajo vojaški vidik Oswaldove osebnosti, ko beležijo njegovo sodelovanje v različnih spopadih med samimi Irci. Različni vladarji na Irskem so z izgnanim Oswaldom ravnali stanu primerno, istočasno pa so pričakovali, da jim bo gostoljubnost povrnil z vojaškim sodelovanjem (MacKenzie 71-78).

\section{Iustum bellum (pravična vojna) in kralj mučenec}

Beda se osredotoči na dve Oswaldovi odločilni bitki: na njegovo zmago nad heretičnim britanskim kraljem Cadwallo pri Heavenfieldu leta 634 (HE 3.1 in 3.2) in na njegov poraz in smrt v bitki pri Maserfeldu leta 642 proti Pendi, poganskemu kralju Mercijcev. V opisu bitke pri Heavenfieldu Beda poudari sovražnikovo številčno premoč in ustvari prizor, brez katerega si ni mogoče predstavljati nobenega zapisa o sv. Oswaldu. Oswald namreč s spremljevalci postavi križ na večer pred bitko in se z molitvijo pripravi na spopad. To je strokovnjake vzpodbudilo, da so potegnili vzporednice med Oswaldom in cesarjem Konstantinom, ki mu je bilo pred znamenito bitko pri Milvijskem mostu leta $314 \mathrm{v}$ sanjah napovedano, da bo zmagal v znamenju križa (Bintley 178-179). Razen tega je Beda predstavil Oswaldovo zmago pri Heavenfieldu kot pravično vojno, iustum bellum, koncept, ki sta se ga poslužili celo taki cerkveni avtoriteti, kot sta bila sv. Avguštin iz Hipona (354-430) in milanski škof Ambrozij (†397), da sta z njim upravičila uporabo vojaške sile pri kristjanih (Hare, Christian 20-23; cf. Cross 270-273; Hill 57-80). Cadwalla je napadalec, tujec, ki zasede in pustoši Northumbrijo in njene prebivalce obravnava kot premagano ljudstvo. Cadwalla je sicer kristjan, toda pripadnik keltskega krščanstva, ki ga je Beda zavračal kot krivoverskega. Bitka proti takemu nepridipravu je stvar časti.

Ob tem se pojavi vprašanje, ali je imel Oswald v resnici tako maloštevilno vojsko, kot trdi Cerkvena zgodovina, ali gre v tem primeru za hagiografski prijem. Težko je verjeti, da bi se Oswald lotil ponovnega osvajanja svojega kraljestva brez ustrezne politične, vojaške in tudi duhovne podpore, pri čemer je potrebno imeti v mislih otok Iono, najvplivnejšo izpostavo irskega krščanstva na Otoku. Da so imeli Irci v resnici velika 
pričakovanja glede Oswaldovega ponovnega vzpona na oblast, je razvidno iz Življenja sv. Kolumbe (Vita sancti Columbae), ki je nastalo bodisi ob koncu sedmega ali v prvih letih osmega stoletja in kjer je zabeležena zanimiva epizoda. Oswaldu se v noči pred bitko v sanjah prikaže sv. Kolumba (521 - 597), ustanovitelj samostana na Ioni, poleg sv. Patricka in sv. Brigid najslavnejši irski svetnik, in mu obljubi zmago (Reeves, 1. knj., 1. pogl.). Ker Oswaldu Kolumba podari zmago, ga s tem zaveže sebi in Ioni in s tem Irski, kajti tisti, ki podari vrednejše darilo, po irski tradiciji dobi moč nad obdarovancem (MacKenzie 183-184).

V nasprotju z Oswaldovo zmagovito bitko pri Heavenfieldu je bila Oswaldova poslednja bitka pri Maserfeldu, v kateri se je soočil s Pendo iz Mercije, za Bedo trd oreh. Poraz krščanskega vladarja v bitki proti poganom je bil za Cerkev nedvomno vir zadreg in tudi Beda ne more skriti nelagodja, zaradi česar je njegov zapis o bitki marsikdaj nejasen. Če se ve, da je bitka pri Heavenfieldu potekala globoko v Northumbriji, je lokacija Maserfelda nejasna. Po najpogostejši razlagi je Maserfeld Oswestry na valižanski meji, v današnjem Shropshiru na zahodu Anglije, po drugi razlagi pa v Lindseyju v osrednji Angliji, na ozemlju, za katero sta tekmovali Northumbrija in Mercija s spremenljivo srečo, dokler ni Lindsey leta 679 dokončno pripadel Merciji. Vsekakor Oswald ni padel znotraj meja svojega kraljestva in njegov globok vpad na tuje ozemlje (Damon \$13) je težko opredeliti kot obrambno in pravično vojno. Roko na srce, tega Beda nikjer ne trdi in pri poročilu o bitki ga zapusti običajna natančnost. Ne pove namreč, kaj je Oswald počel na sovražnikovem ozemlju in zakaj je sploh prišlo do vojne, namesto tega pa pripiše Oswaldu v njegovih poslednjih trenutkih vedenje, ki ga povezuje z mučeniki in njihovim odklanjanjem vojaškega nasilja. Beda trdi, da je Oswald ob spoznanju, da je smrt blizu, molil za duše svojih vojakov. S tem se ustvari vtis, kot da se Oswald v svojih poslednjih trenutkih sploh ni hotel več boriti, ampak se je preselil iz območja vojaškega v območje duhovnega.

Tu je ponovno mogoče opaziti povezavo s sv. Martinom (316-397), ki je bil svoj čas vojak, kar so mu nasprotniki v Cerkvi radi oponašali. Sulpicij Sever, njegov prvi biograf, je zato poskušal karseda oslabiti vojaški element v svoji biografiji o sv. Martinu. Tako je podaril, da je Martin stopil v vojsko pri petnajstih letih proti svoji volji in da se je dokončno uprl vojaški službi v času Julijana Odpadnika (361-363). Tedaj je prišlo do čudeža. Ker se Martin ni hotel boriti proti sovražni vojski, je bil zaprt. Da bi zavrnil obtožbo strahopetnosti, se je bil pripravljen sam soočiti s sovražno vojsko, vendar brez potrebe, ker so sovražniki sami zaprosili za mir (Francese 4. pogl.). 
Na dlani je, da za Bedo Oswaldova poslednja bitka predstavlja vir zadreg. Kralj, ki postane mučenec, ker pade v bitki, pa čeprav s pogani, mu pač ne gre v račun. Tudi ni jasno, za čigave duše je Oswald pravzaprav molil, za duše svojih ali tudi mercijskih vojakov (Damon $\$ 15$ ). Bedov zapis o bitki daje slutiti, da je bilo v resnici težko narediti svetnika mučenca iz kralja, ki je bil znan po svojih vojaških uspehih, saj je bil poimenovan Bretwalda, vladar nad celotno Britanijo (HE 3.6). Bilo je lažje opisati Oswalda kot vzornega vladarja, v slogu vrlih vladarjev iz Stare Zaveze, ki skrbi za svojo državo in njene prebivalce (Burch 148-149), kot pa mučenca, ki odklanja telesno, vojaško nasilje in daje prednost duhovnemu boju. Opis bitke daje slutiti, da je imel Beda težavo, ko je poskušal spraviti na skupni imenovalec dve nasprotujoči si načeli: mučenec, ki zavrne vojaško nasilje in ne more sovražiti nasprotnikov, in vladar, ki širi meje svojega kraljestva, katerega blaginja je bila življenjsko odvisna od vladarjevih dosežkov na bojnem polju.

\section{Aebbe (ok. 615-683) - opatinja, tesna sorodnica kronanih glav in prijateljica škofov}

Beda nikakor ne podaja Oswaldovega življenjepisa v celoti, ker ga zanimajo izključno tista Oswaldova dejanja, ki so pripomogla k vzponu krščanstva med Anglosasi. Toda kljub temu da lahko na osnovi njegove Cerkvene zgodovine samo približno rekonstruiramo Oswaldovo življenje in delo, je poročilo o Oswaldu vseeno presenetljivo podrobno v primerjavi z Bedovim zapisom o Oswaldovi edini sestri Aebbe. Beda Aebbe v svoji obsežni Cerkveni zgodovini omeni samo dvakrat, in sicer v svoji četrti knjigi. Prvič jo omeni kot opatinjo Coldinghama, kjer je opravljala noviciat prva Ecgfrithova žena, sv. Eteldreda, najbolj znana angleška svetnica vseh časov (HE 4.19), drugič pa poda nekaj namigov o Aebbinem neprimernem vodenju omenjenega samostana, ki ga je sama ustanovila (HE 4.25).

Po Bedovih namigih sodeč, Aebbe samostana ni vodila dovolj odločno, zato se je v njem razpasla nedisciplina in po njeni smrti je samostan pogorel in ga niso več obnovili. Coldingham je bil tako imenovani dvojni samostan, sestavljen iz dveh ločenih skupnosti redovnikov in redovnic, ki jima je načelovala ista opatinja. Beda namiguje, da ni šlo samo za lagodno in razkošno življenje in zanemarjanje bogoslužja, temveč tudi za spolne odnose med redovniki in redovnicami. Beda sicer poudari, da je bila Aebe sama osebno poštena in brez greha in da je samostan pogorel šele po njeni smrti. Propad samostana je 
opatinji napovedal menih Adomnan, eden od članov skupnosti. Svarilo je za nekaj časa zaleglo, toda kmalu je življenje v samostanu spet teklo po starih tirnicah in po Aebbini smrti je samostan doživel svojo usodo.

Zanimivo je, da Beda o Aebbe razen teh dveh drobcev ne pove ničesar več v svoji Cerkveni zgodovini, toda kljub kriptični naravi svojih dveh zapisov le sporoči pomemben podatek. Aebbe je bila teta kralja Ecgfritha, v svojem Življenju sv. Cuthberta, ok. 721, ki je bil poleg Oswalda najpomembnejši svetnik na angleškem severu, pa še doda, da je bila Aebbe (pol)sestra kralja Oswyja (»soror uterina regis Oswy«; Colgrave, Two Lives 188-189). To se prevaja kot polsestra po materi, vendar v Aebbinem primeru ta podatek ni nikjer pojasnjen. Sv. Cuthbert (ok. 634-687) je bil silno priljubljen med vsemi sloji northumbrijske družbe, prav tako se ni izogibal stikom z visoko družbo, kjer so imele kraljevske opatinje zelo pomembno vlogo (Campbell 10-11), kar vsaj deloma pojasni razširjenost in trdoživost njegovega kulta. Aebbe ga je povabila v Coldingham, svetnik je njeno vabilo sprejel in ostal v samostanu nekaj dni. Zanimivo je, da v zapisu ni namigov, da bi bilo $s$ samostanom kaj narobe, večina zapisa o njegovem bivanju v samostanu je namreč namenjena čudežem, do katerih je prišlo v času svetnikovega obiska.

Podobno pripoved podaja tudi anonimno Življenje sv. Cuthberta, ki je nastalo v Lindisfarnu okrog leta 700. Tudi tu Cuthbert obišče Coldingham in tudi tu je poudarjeno, da ga je povabila Aebbe, o kateri Življenje ne pove, da je bila v sorodu z Oswyjem, poda pa podatek, da je bila vdova, vendar brez dodatnih pojasnil (Colgrave, Two Lives 80-81). Prav tako ni rečeno, da bi Cuthbert karkoli kritiziral v samostanu, glavnina prostora je tako kot pri Bedi tudi tu namenjena že prej omenjenim čudežem. Aebbe pa je omenjena še v Življenju sv. Wilfrida (začetek osmega stoletja), kjer je prikazana $\mathrm{v}$ zelo pozitivni luči kot zaveznica škofa Wilfrida. Ona je bila namreč tista, ki je leta 681, na višku spora med kraljem in škofom, prepričala svojega nečaka kralja Ecgfritha, naj izpusti Wilfrida iz zapora, ko se je kralj mudil v Coldinghamu s svojo drugo kraljico (Colgrave, The Life 78-79).

Podatki o Aebbe so torej silno skopi (Eckenstein 101-102), vseeno pa je mogoče na osnovi ohranjenih drobcev tvegati nekaj sklepov. Aebbe je bila Oswyjeva (pol)sestra in teta kralja Ecgfritha, anonimno Življenje sv. Cuthberta pa zadržano omeni, da je bila vdova (Colgrave, Two Lives 81; Ziegler, "The politics«). Kakšen je bil njen odnos s (pol)bratoma, Oswaldom in Oswyjem, ki ju je oba preživela, ni povedano, mogoče pa je sklepati, da je bil dober ali vsaj primeren, drugače bi težko ustanovila kar dva samostana, Ebchester in Coldingham, ker je bila ustanovitev 
samostana draga investicija, ki so si jo lahko privoščile le redke ženske iz najožjega vladarjevega kroga. Bedov zapis v Cerkveni zgodovini namiguje, da Aebbe ni imela ustreznih vodstvenih sposobnosti, ki bi ji omogočile voditi samostan z mešanico avtoritete, strogosti in karizme, zaradi katere sta bili tako zelo cenjeni Hilda iz Whitbyja v Northumbriji (HE 4.23-24) in sv. Eteldreda, opatinja znanega samostana v Elyju v Vzhodni Angliji (HE 4.19-20), ki jima Beda odkaže častno mesto v svoji Cerkveni zgodovini. Ker je Cerkvena zgodovina zlasti v četrti knjigi sestavljena pretežno iz vzornih škofov, opatov, menihov in opatinj, Aebbin primer toliko bolj izstopa. 4. knjiga se prav tako posveča vladarjem in Beda omeni mnoge med njimi, ki so imeli zasluge pri vzponu krščanstva med Anglosasi. Toda Ecgfritha ni med njimi. Ta vladar se je rad spuščal v tvegane in škodljive spopade, kar ga je leta 685 stalo življenja. Usodni pohod je organiziral kljub Cuthbertovim izrecnim svarilom in $s$ tem pokazal nespoštovanje do cerkvene avtoritete, kar je bilo zanj usodno (HE 4.26). Po Cerkveni zgodovini sodeč, sta Ecgfrith in Aebbe črni ovci med uspešnimi vladarji in vzornimi opatinjami (Higham, "Bede's Agenda" 8-9, 19-20). To dejstvo Cerkvena zgodovina še dodatno podčrta z vrstnim redom zapisov o njunih polomih. Poročilu o Aebbinem neuspešnem vodenju samostana (HE 4.25) namreč takoj za tem sledi zapis o Ecgfrithovem porazu in smrti (HE 4.26).

Toda $\mathrm{v}$ sedmem stoletju in $\mathrm{v}$ začetku osmega so bile cerkvene razmere kljub Aebbinemu in Ecgfrithovemu zdrsu še vedno pod nadzorom. Anglosasi, v Bedovih očeh Izvoljeno ljudstvo, so razširili krščanstvo po celotnem Otoku, nato pa so ob koncu sedmega in v začetku osmega stoletja uspešno pokristjanjevali svoje germanske sorodnike na Kontinentu. Lahko rečemo, da je Bedova Cerkvena zgodovina zanosen in idealiziran opis zgodovine krščanstva od dobe Rimljanov do Bedovega lastnega časa, v kateri odigrajo Angli oziroma Anglosasi glavno vlogo in ki so jim namenjene kar štiri od petih knjig (Sellar 3-8). Beda, ki je bil rojen 673 in umrl 735, seveda ni doživel časov sv. Oswalda in Oswyja, toda dočakal je tragično smrt kralja Ecgfritha (leta 685), nasilno smrt kraljice Ostryth (leta 697) in doživel vladavino Ecgfrithovega polbrata Aldfritha (685-705), turbulentno vladavino njegovih sinov Osreda $(† 716)$ in Osrica $(† 729)$ in vzpon novih vladarjev iz stranskih vej. Prav tako je preživel sv. Cuthberta $(\dagger 687)$, sv. Wilfrida (†709), sv. Eteldredo $(† 679)$ in sv. Hildo iz Whitbyja (†680), ki so bili nosilci razvoja krščanske kulture v Northumbriji in ikonični liki, brez katerih si ni mogoče predstavljati zgodovine Anglije.

Toda sedanjost prve tretjine osmega stoletja, ki jo je opazoval Beda, je bila manj vzpodbudna: vrsta vladarjev $s$ kratkim rokom trajanja in 
razcvet neprimernih praks v Cerkvi. Da se je Beda tega zavedal, dokazuje njegovo pismo nekdanjemu učencu, škofu in poznejšemu nadškofu Egbertu iz Yorka ter bratrancu kralja Ceolwulfa, ki mu je posvečena Cerkvena zgodovina (Giles 138-155). V pismu je kritičen zlasti do kvazisamostanov, ki so jih ustanavljali plemiči, da bi na ta način obdržali v trajni lasti zemljo, ki so jo dobili od kralja (Kubrusly de Freitas 136-138). Tovrstni kvazisamostani so bili razvpiti zaradi izrazito posvetnega življenja in družbeno škodljivi, ker so posvetni oblasti trajno odtujevali zemljo, $s$ katero je plačevala posvetno vojaško aristokracijo. Ker za posvetne plemiče ni bilo dovolj zemlje, so zapuščali deželo, zaradi česar je trpela obrambna moč države (Hodgkin 417). Bedo je prav tako skrbela navezanost menihov na plemiško vojaško kulturo (Hare, "Heroes« $\$ 17$ ), ki po Bedovem mnenju ni sodila v meniško okolje. Anglosaška plemiška družba, posvetna in duhovna, je bila navezana na izročila predkrščanske dobe, na junaški etos in plemiški način življenja ter je iskala navdih $\mathrm{v}$ germanskih junaških legendah. Samostani so pri tem igrali pomembno vlogo. $\mathrm{V}$ zapisih so ohranili marsikatero starogermansko pesnitev in tudi $\mathrm{v}$ življenjih svetnikov in pesnitvah o junakih iz Stare Zaveze je opazno poudarjanje tradicionalnega junaškega etosa (Divjak 140-142).

Toda Beda nikakor ni bil edini, ki je v osmem stoletju z zaskrbljenostjo spremljal upad redovniške discipline in znižane moralne standarde v Cerkvi anglosaške Anglije. Sinoda iz leta 747 v neugotovljenem "Cloveshu« (verjetno blizu Londona) je prav tako opozarjala na pešajočo disciplino menihov in redovnic, ki bi morali živeti tiho, urejeno življenje in ne bi smeli nositi bahaških in razkošnih oblek, in na njihov posvetni življenjski slog (Hodgkin 417). Tudi sv. Bonifacij (672-754), Zavetnik Nemčije, najbolj znani anglosaški misionar, ki je sodeloval pri cerkvenih reformah $\mathrm{v}$ frankovskem kraljestvu in spreobračal pogane, je bil kritičen. V svojem pismu, namenjenemu canterburyjskemu nadškofu leta 747 , je kritiziral svoje rojake zaradi romanja žensk v Rim, ki so pogosto končale kot prostitutke v Lombardiji, Franciji in Galiji, menihe pa zaradi razkošnega oblačenja in pijanosti (Hodgkin 419-420). Tretji evropsko znani Anglosas Alcuin (ok. 737-804), rojen v Northumbriji, in eden najbolj znanih predstavnikov karolinške renesanse, je prav tako opozarjal v svojih pismih na neprimerno vedenje v northumbrijskih samostanih: na spolne prekrške, pohlep, požrešnost, pijanost, posvetnost, nečimrnost, ljubezen do športa, lova in pojedin ter neprimerno občudovanje predkrščanske junaške poezije (Hodgkin 420). 


\section{Aebbin kult - rehabilitacija po 400 letih}

V luči vseh teh dejstev je razumljivo, zakaj Aebbe v anglosaški dobi, niti zgodnji niti poznejši, ni imela možnosti, da bi jo razglasili za svetnico. Razmere so se začele spreminjati šele na začetku dvanajstega stoletja, ko je doživljal kult sv. Cuthberta ponovno rojstvo, in z njim mesto Durham v severovzhodni Angliji, kamor so leta 995 preselili svetnikove posmrtne ostanke (Hodgkin 555-556). Ob tej priložnosti je Katedrala v Durhamu, ki je varovala svetnikove posmrtne ostanke, pokazala veliko zanimanje tudi za druge anglosaške svetnike, Cuthbertove sodobnike ali neposredne predhodnike in naslednike, ki so tako kot Cuthbert izvirali iz severne Anglije. Tako Symeon iz Durhama (dejaven med ca. 1090 in 1128) poroča v svoji Razpravi o izvoru in napredku Cerkve v Durhamu (Libellus de exordio atque procursu istius, hoc est Dunhelmensis, ecclesie), da je Alfred Westou (dejaven ok. 1020 in po 1056), ki je bil zadolžen za zakristijo v Katedrali, po Cuthbertovem ukazu potoval po Northumbriji, zbiral posmrtne ostanke svetnikov in jih prenesel $\mathrm{v}$ Durham. Med njimi so najbolj znani sv. Oswin, sv. Beda Častitljivi in sv. Aebbe, medtem ko je Durham že od prej imel v varstvu poleg sv. Cuthberta tudi glavo sv. Oswalda. Katedrala v mestu je bila očitno odločena, da bo svojo prepoznavnost gradila na anglosaških svetnikih, povezanih z nekdanjim kraljestvom Northumbrijo, s Cuthbertom kot osrednjo svetniško figuro. Pri tem je Katedrala nastopila toliko bolj energično, ker je istočasno tudi Glastonbury, sloveč samostan na jugozahodu Anglije, trdil, da hrani posmrtne ostanke mnogih svetnikov, ki jih je hotel imeti zase Durham (Whitehead 5-6).

Cerkveno zanimanje za Aebbe, ki je po priljubljenosti prehitela vse v Durhamu pokopane svetnike, z izjemo Cuthberta in Oswalda (Whitehead 9-11), je imelo praktičen značaj. Na začetku dvanajstega stoletja je škotski kralj Edgar (1097-1107) izročil Coldingham Katedrali v Durhamu, ${ }^{1}$ ki je v Coldinghamu okr. leta 1139 ustanovila samostan. Da bi se novi samostan, ki je politično spadal pod Škotsko, duhovno in cerkveno pa pod Anglijo, laže utrdil, je potreboval lokalnega svetnika nedvoumnega northumbrijskega izvora, iz najstarejše dobe (Whitehead 7). Aebbe kot ustanoviteljica prvotnega samostana in sestra legendarnega sv. Oswalda je bila idealna izbira toliko bolj, ker je njen samostan sodil pod duhovni vpliv Lindisfarna, kjer je bil svoj čas škof tudi sv. Cuthbert. Razen tega ji je dodatno prepoznavnost

${ }^{1} \mathrm{~V}$ začetku enajstega stoletja je postal Berwickshire, kamor je sodil Coldingham, del škotskega kraljestva in je še danes del Škotske. 
prineslo njeno poznanstvo $s$ sv. Eteldredo, ki je bila $v$ dvanajstem stoletju slavna svetnica, Ely, kjer je bila pokopana, pa je v dvanajstem stoletju sodil med tri ali štiri najpomembnejša angleška romarska središča (Whitehead 10-11).

Tako se je v šestdesetih, sedemdesetih letih dvanajstega stoletja sv. Aebbe pojavila v liturgičnem besedilu iz Coldinghama, omenjena je $v$ koledarjih iz istega stoletja, in sicer sta navedena dva njena duhovna "rojstna" datuma, 2. 11. in 25. 8. (Whitnah 209), v devetdesetih letih istega stoletja pa je nastalo osrednje hagiografsko besedilo Vita et Miracula Sancte Ebbe Virginis, ki ga je zelo verjetno napisal Reginald iz Durhama.

Aebbin kult je zanimiv. Ni namreč popolnoma jasno, kaj se pravzaprav skriva v Aebbini krsti, ki so jo po Življenju sv. Ebbe odkrili pastirji na mestu prvotnega, Aebbinega, samostana na rtu (St Abb's Head) in prenesli v cerkev novega samostana v Coldinghamu. Njeno Življenje je na tem področju nejasno, ker noče ali si ne upa zanikati trditev Symeona iz Durhama, da Aebbini posmrtni ostanki počivajo v Durhamu, ki je bil Coldinghamu nadrejen, zato najbrž ni bilo pametno postavljati pod vprašaj prepričanj, ki jih širila matična ustanova (Whitehead 17-18). Še bolj zanimivo pa je, da je bilo središče kulta na rtu in tam se je - po trditvah hagiografskih zapisov - od dvanajstega stoletja naprej zgodila večina čudežev, in ne v cerkvi $\mathrm{v}$ novem samostanu $\mathrm{v}$ Coldinghamu (Powell 74-75, 84-85). Menihi so po letu 1188 na na rtu zgradili oratorij, medtem ko je bil novi samostan v Coldinghamu s krsto sv. Aebbe oddaljen kakšni dve milji od rta (Whitnah 214-215). Dejstvo, da so se njeni čudeži dogajali večinoma v oratoriju na rtu, je menihom v Coldinghamu popolnoma ustrezalo. Zaradi podrejenosti Durhamu se niso mogli razglasiti za varuhe njenih posmrtnih ostankov, upravičeno in brez ovir pa so se imeli za gospodarje pokrajine okrog Coldinghama, zlasti rta, kamor so se najprej povzpeli verniki, željni ozdravitve, ki so šele pozneje odšli v samostansko cerkev.

Življenje zelo na kratko opravi z življenjem sv. Aebbe, in sicer v enem samem poglavju, medtem ko je ves preostali zapis namenjen njenim čudežem. Se bolj pomembno je, da je Aebbe v Življenju predstavljena kot devica, ki odkloni mogočnega snubca in se zateče na rt, ki se čudežno spremeni v otok, kar Aebbinemu snubcu prepreči dostop do svetnice (Whitnah 219-221). Življenje tudi ne prikriva dejstva, da je vladala v samostanu nedisciplina (Whitehead 15-16), vendar preusmeri pozornost $s$ te nerodnosti na ozdravitvene čudeže, za katere je bila zaslužna Aebbe.

Aebbe so v dvanajstem stoletju prepoznavali kot svetnico, ki je pomagala pri paralizi, slepoti, otekanju, norosti, naglušnosti in nemosti. 
Pri zadnjih dveh težavah je bila domnevno zelo uspešna, zlasti pri otrocih (Bailey 278, 283; Salter 92, 95, 99, 103, 104). Zanimivo je, da so se $\mathrm{k}$ njej zatekale večinoma mlade in revne ženske (Bartlett xxiii-xxiv), medtem ko je Durham ostajal strogo maskuliniziran (Whitehead 22).

Menihom v Coldinghamu je uspelo. Neugodna dejstva o Aebbe so znali obrniti v svojo korist. Vdovo so spremenili v devico, ki se z božjo pomočjo ubrani vsiljivega snubca in vtisne trajni pečat pokrajini, kjer je ustanovila samostan. Znali so tudi preusmeriti pozornost romarjev z Aebbinih nedoločljivih posmrtnih ostankov v krsti, pokopanih $\mathrm{v}$ novem samostanu, na pokrajino in oratorij na rtu, ki je bil nedvoumno povezan z Aebbe, njeno dvomljivo vodenje samostana pa so zasenčili ozdravitveni čudeži (Bartlett xxvii-xxviii).

\section{Sklep}

Članek ugotavlja, da so med svetostjo, pripisano sv. Oswaldu, in med svetostjo, pripisano sv. Aebbe, vladale občutne razlike, prav tako pa je tudi razvoj njunih kultov tekel po zelo različnih tirnicah. Oswaldov kult se je uveljavil kmalu po Oswaldovi smrti, za kar so zaslužni zlasti Oswaldov brat Oswy in prebivalstvo, medtem ko je bila Cerkev prvotno zadržana. Aebbe, nasprotno, ni veljala za svetnico niti v zgodnji niti v pozni anglosaški dobi in šele $\mathrm{v}$ dvanajstem stoletju, dobrih štiristo let po njeni smrti, je prišlo do vzpostavitve kulta, za kar sta bili zaslužni Katedrala v Durhamu in na novo zgrajeni samostan v Coldinghamu. Razen tega je Oswald svoje vladarske naloge zgledno opravljal, medtem ko Aebbe - vsaj po namigih v Bedovi Cerkveni zgodovini - ni bila zgled uspešnega vodenja samostanske skupnosti. Posledično je Oswald užival bistveno višjo stopnjo vidljivosti in naše vedenje o njem je - kljub lakunam - solidno. Abbe, nasprotno, ostaja izmuzljiva in skrivnostna in o njenem življenju ne vemo skoraj nič.

Prav tako si ohranjeni hagiografski zapisi prizadevajo oba svetnika kar se da prilagoditi hagiografskim konvencijam. Pri Oswaldu zamolčijo dinastične napetosti, krčijo poročila o njegovi vojaški dejavnosti in rahljajo njegove vezi s posvetnim svetom. Aebbina šibka točka je bila samostanska disciplina, zato je bilo potrebno preusmeriti pozornost $\mathrm{z}$ njenega neuspešnega vodenja samostana na številne ozdravitvene čudeže, ki so se domnevno dogajali v Coldinghamu po njenem posredovanju. Prav tako je hagiografija predstavila Aebbe kot neporočeno princeso, ki se uspešno izogne nezaželenemu snubcu, $s$ čimer se dvigne njen ugled $\mathrm{v}$ svetniški srenji. 
Če povzamemo, kulta sv. Oswalda in sv. Aebbe sta bila vzpostavljena, ko sta obstajali za to volja in potreba. Oswaldova družina je v sredini sedmega stoletja potrebovala nebeškega zaščitnika, ki ji je pomagal utrditi oblast $\mathrm{v}$ kraljestvu, medtem ko je ponovno zgrajeni samostan v Coldinghamu v dvanajstem stoletju potreboval Aebbe kot svetnico zavetnico. $\mathrm{Z}$ drugimi besedami, politične in cerkvene potrebe so $\mathrm{v}$ točno določenem obdobju spodbudile nastanek kulta in vplivale na hagiografske zapise, ki so lahko zgodovinsko osebo v imenu višjih ciljev spremenili tudi do nerazpoznavnosti. Le tako je lahko vladar, ki je vdrl globoko na tuje ozemlje in bil pri tem poražen, ubit in obglavljen, postal mučenec in borec proti poganom, njegova ovdovela sestra, ki ni imela sreče z vzdrževanjem samostanske discipline, pa sveta devica in strokovnjakinja za čudežne ozdravitve.

VIRI

Bartlett, Robert, ur. in prev. The Miracles of Saint Aebbe of Coldingham and Saint Margaret of Scotland. Oxford: Clarendon Press, 2003.

Beda Venerabilis. Epistula ad Ecgberctum antistetem. <https://www.intratext.com/ IXT/LAT0421/>

Beda Venerabilis. Historia Ecclesiastica Gentis Anglorum.

Colgrave, Bertram, ur. in prev. The Life of Bishop Wilfrid by Eddius Stephanus. Text, translation and notes. Cambridge: Cambridge University Press, 1940.

Colgrave, Bertram, ur. in prev. Two Lives of Saint Cuthbert. A Life by an Anonymous Monk of Lindisfarne and Bede's Prose. Life, Texts, translation and notes. Cambridge: Cambridge University Press, 1940.

Francese, Christopher, ur. Sulpicius Severus: Life of St. Martin. Carlisle, Pennsylvania: Dickinson College Commentaries, 2011.

Giles, J. A., ur. The historical works of Venerable Bede. Vol. 2. London: James Bohn, 1845.

Reeves, William, ur. Life of Saint Columba, Founder of Hy. Written by Adamnan, Ninth Abbot of that Monastery. Edinburgh: Edmonston and Douglas, 1874.

Sellar, A. M., ur. Bede's Ecclesiastical History of England. A Revised Translation with Introduction, Life, and Notes. London: George Bell and Sons, 1907.

\section{LITERATURA}

Bailey, Anne E. »Miracle Children: Medieval Hagiography and Childhood Imperfection«. Journal of Interdisciplinary History 47.3 (2017): 267-285.

Bintley, Mike. "The translation of St Oswald's relics to New Minster, Gloucester: royal and imperial resonances". Anglo-Saxon Studies in Archaeology and History 19 (2014): 171-181.

Burch, Peter J. W. The Origins of Anglo-Saxon Kingship. Doctoral Thesis. Manchaster: University of Manchester, Faculty of Humanities, 2015. <https://www.research. manchester.ac.uk/portal/files/54581865/> 
Campbell, J. "Elements in the Background to the Life of St Cuthbert and his Early Cult«. St. Cuthbert, His Cult and His Community to A.D. 1200. Ur. Gerald Bonner, David Rollason in Claire Stancliffe. Woodbridge: The Boydell Press, 1989. 3-20.

Cross, J. E. "The Ethic of War in Old English«. England before the Conquest. Ur. Kathleen Hughes in Peter Clemoes. Cambridge: Cambridge University Press, 1971. 269-282.

Cubitt, Catherine. "Sites and sanctity: revisiting the cult of murdered and martyred Anglo-Saxon kings". Early Medieval Europe 9.1 (2000): 51-83.

Damon, John Edward. "The King's Fragmented Body: A Girardian Reading of the Origins of St Oswald's Cult«. The Heroic Age 9 (2006). Splet. 26. 3. 2020. $<$ https://www.heroicage.org/issues/9/damon.html>

Divjak, Alenka. »The exploitation of heroic conventions in the OE poem Andreas: an artistic misconduct or a convincing blend of traditional literary concepts and new Christian ideas?". Acta neophilologica 45.1/2 (2012): 139-152.

Dyson, Gerald. »Kings, Peasants and the Restless Dead: Decapitation in Anglo-Saxon Saints' Lives". Retrospectives 3 (2014): 32-43.

Eckenstein, Lina. Woman under Monasticism. Chapters on saint-lore and convent life between A.D. 500 and A.D. 1500. Cambridge: Cambridge University Press, 1896.

Foot, Sarah. »Bede's Kings". Writing, Kingship and Power in Anglo-Saxon England. Ur. Rory Naismith in David A. Woodman. Cambridge: Cambridge University Press, 2017. 25-51.

Hare, Kent G. Christian Heroism and Holy War in Anglo-Saxon England. Baton Rouge: Louisiana State University Press, 1997.

Hare, Kent G. »Heroes, Saints, and Martyrs: Holy Kingship from Bede to Aelfric«. The Heroic Age 9 (2006). Splet. 26. 5. 2020. <https://www.heroicage.org/issues/9/ hare.html>

Higham, N. J. »Bede's Agenda in Book IV of the Ecclesiastical History of the English People: A Tricky Matter of Advising the King". The Journal of Ecclesiastical History 64.3 (2013): 1-28.

Higham, N. J. "The Shaved Head Shall not Wear the Crown". Royal Authority in Anglo-Saxon England. Ur. Gale R. Owen-Crocker in Brian W. Schneider. Oxford: Archaeopress, 2013. 7-16.

Hill, Joyce. "The Soldier of Christ in Old English Prose and Poetry«. Leeds Studies in English 12 (1980-81): 57-80.

Hodgkin, Robert H. A History of the Anglo-Saxons. Vol. 2. Oxford: Oxford University Press, 1952.

Kubrusly de Freitas, Diogo. "Of When It Was Necessary to Remind a Bishop of His Duties: Looking into Bede's Letter to Egbert of York". Veredas da História 10.2 (1982): 128-147.

MacKenzie, Scott Hutcheson. Saint Oswald, Christ and The Dream of the Rood. Mutable signs at a Cultural Crossroad. Doctoral Thesis. Knoxville: University of Tennessee, 2010. <https://trace.tennessee.edu/utk_graddiss/897>

Mertens, Andre. The Old English Lives of St Martin of Tours. Edition and Study. Göttingen: Universitätsverlag Göttingen, 2017.

Moisl, Herman. "Anglo-Saxon Royal Genealogies and Germanic oral tradition«. Journal of Medieval History 7.3 (1981): 215-248.

Pengelley, Oliver. Rome in Ninth Century Anglo-Saxon England. Doctoral Thesis. Oxford: University of Oxford, 2010.

Powell, Hilary. »Pilgrimage, Performance and Miracle Cures in the Twelfth-Century Miracula of St Æbbe«. Medicine, Healing and Performance. Ur. Effie GemiIordanou idr. Oxford: Oxbow Books, 2014. 71-85. 
Rollason, D. W. "List of saints' resting places in Anglo-Saxon England «. Anglo-Saxon England 7 (1978): 61-93.

Runstedler, Curtis. "Saintly Bodies, Cult, and Ecclesiastical Identity in Anglo-Saxon Northumbria". Postgraduate English Journal 32 (2016): 1-18.

Salter, R. J. "Only Half Healed: The Unusual Accounts of the Deaf and Mute in Twelfth Century English Hagiography". Selected Proceedings from 'The Maladies, Miracles and Medicine of the Middle Ages', March 2014. The Reading Medievalist: A Postgraduate Journal. Vol. 2. Ur. Salter, R. Reading: University of Reading, The Graduate Centre for Medieval Studies, 2015. 85-108. <https://blogs.reading. ac.uk/trm/files/2015/04/Salter-R.-Only-Half-Healed.pdf>

Stancliffe, Clare. "Kings who Opted Out". Ideal and Reality in Frankish and AngloSaxon Society. Ur. Patrick Wormald. Oxford: Blacwkell, 1983. 154-176.

Swanton, Michael. English Literature before Chaucer. London: Longman, 1987.

Thacker, Alan. "Membra Disjecta: the Division of the Body and the Diffusion of the Cult«. Oswald, Northumbrian King to European Saint. Ur. Clare Stancliffe in Eric Cambridge. Stamford: Paul Watkins, 1995. 97-127.

Turner, Sam, in Chris Fowler. »The bones of the Northumbrian landscape: technologies of social change in the conversion period «. Making Christian Landscapes in Atlantic Europe. Conversion and Consolidation in the Early Middle Ages. Ur. Tomás Ó Carragáin in Sam Turner: Cork: Cork University Press, 2016. 249-263.

Whitehead, Christiania. "A Scottish or English Saint? The Shifting Sanctity of St Aebbe of Coldingham". New Medieval Literatures 19. Ed. Philip Knox, Kellie Robertson in Wendy Scase Laura Ashe. Woodbridge; Rochester: Boydell \& Brewer, 2019. 1-42.

Whitnah, Lauren. »Reshaping History in the Cult of Æbbe of Coldingham Chapter«. Medieval Cantors and their Craft Book Subtitle: Music, Liturgy and the Shaping of History, 800-1500. Ur. Katie Ann-Marie Bugyis, A. B. Kraebel in Margot E. Fassler. Woodbridge: York Medieval Press, 2017. 207-221.

Ziegler, M. »The politics of exile in early Northumbria». The Heroic Age 2 (1999). Splet. 12. 2. 2020. <https://www.heroicage.org/issues/2/ha2pen.htm>

Ziegler, M. "Through His Enemy's Eyes: St. Oswald in the Historia Brittonum«. The Heroic Age 9 (2006). Splet. 12. 2. 2020. <https://www.heroicage.org/issues/9/ ziegler.html> 


\section{A King Martyr and a Merry Abbess: Two Atypical Saints from the Same Family Nest}

Keywords: Church history / christianity / 7th century / Northumbria / monasticism / saints / St. Oswald of Northumbria / St. Aebbe of Coldingham

This article juxtaposes the activities of two saints, brother and sister, St Oswald (634-642) and St Aebbe (ca. 615-683), members of the royal family of Northumbria, and discusses their rather unconventional paths to sanctity. Oswald's efficiency and competent kingship were instrumental in reconverting Northumbria to Christianity, laying thus the foundations for the intellectual and spiritual growth of Christianity in Northumbria. Nevertheless, the Church of Northumbria was initially reluctant to raise Oswald to sanctity, and this reluctance ran against the wishes of Oswald's family and the majority of the population. Aebbe, on the other hand, was fully absorbed in the monastic sphere as an abbess and foundress of the monastic community at Coldingham (today's southern Scotland). However, if Oswald's achievements were fully recognized soon after his demise, Abbe's leadership of her monastic community seems to have been controversial. Oswald's cult began to be promoted soon after his death, Aebbe, by contrast, was never regarded as a saint in the Anglo-Saxon period. Her cult began to emerge only in the twelfth century when the recently established monastery in Coldingham needed a saintly predecessor and unlike her brother's cult, it never held an international appeal. Nevertheless, she was a respected local saint, notable for her numerous curative miracles, and her rise from oblivion remains a telling example of ecclesiastical spin in the field of the veneration of saints.

1.01 Izvirni znanstveni članek / Original scientific article

UDK $27-36$

DOI: https://doi.org/10.3986/pkn.v43.i3.05 